\title{
移動ロボット相互の位置・姿勢実時間計測システムの開発
}

\author{
新井民夫*1 木村 久幸*2 前田 健太郎*3 \\ 太田順 ${ }^{* 1}$ 梅田和 昇*1

\section{Development of Real-Time Position/Orientation Measuring System for Multiple Mobile Robot System}

\author{
Tamio Arai ${ }^{* 1}$, Hisayuki Kimura*2, Kentaro Maeda*3, \\ Jun $\mathrm{Ota}^{* 1}$ and Kazunori Umeda*1
}

\begin{abstract}
Measuring relative positions among robots are essential to avoid collision and to coordinate one another. This paper proposes a signboard system and an algorithm to measure the relative positions among mobile robots in real -time. The system consists of a CCD camera and signboards with LEDs, whose 2D images are obtained by a CCD camera loaded on a different robot. The algorithm first separates the image into each signboard, and second detects the position and the orientation of the target robot. Error analysis made it possible to measure the orientation of the target robot in 360 degree with the minimum errors. The experiments with 3 mobile robots indicates that one robot can measure the other two position with the accuracy of $5 \%$ in distance within 0.4 second, in the range of 0.5 to 3 meters. The measuring speed is fast enough to calcuate the collision avoidance. The experiments verified the system is very efficient.
\end{abstract}

Key Words: Multiple Mobile Robots, Position Sensing, Image Processing, Error Analysis

\section{1. 序 論}

移動ロボットの適用環境がオフィス・家庭へと広がり, 要求 される作業が高度になるにつれて，一つの環境内に複数台の口 ボットが存在する複数移動ロボット系の研究が重要となってい る[1].この系においては，ロボット同士の衝突回避や能動的 な協調のために，ロボット相互の位置・姿勢を実時間で計測す ることが不可欠である. しかしながら，ロボットの位置・姿勢 計測に関する従来の研究は, 環境内に固定されたランドマーク [2][3]や, レンジファインダ[4]を用いることによりロボッ 卜の自己位置・姿勢を同定する研究が大半であった. 複数台の ロボットの相対位置・姿勢を相互に計測に関する研究は少なく [5]，ロボット間通信を用いた方法 [6]が見られる程度であっ た.

本研究では, 複数移動ロボット系における相互位置・姿勢を 光源とカメラを用いて実時間計測するシステムを提案し, 誤差 解析から光源を最適配置する設計方法を示す．実機を用いた実

\footnotetext{
原稿受付 1993 年 4 月 8 日

*1東京大学工学部

*2神奈川県立商工高校

*3新日本製鐵(株)

* Faculty of Engineering, Univerisity of Tokyo

${ }^{*}$ Kanagawa Prefectural Shoko Commercial and Technical High School

${ }^{*}$ Nippon Steel Corporation
}

験により理論の有効性を検証する.

\section{2. システムの基本構想}

\section{1 測定系の基本設計}

本研究で提案するシステムの適用環境として,

(1) 環境内には, 複数台のロボットのみが存在する,

(2) 通常の明るさの室内である,

(3) 床面は平坦で, ロボットは滑らかに走行する. よって, 口 ボットの倒れは無視できる,

(4) 各移動ロボットは自律分散制御を行う, を仮定する．これらの仮定は，移動ロボットの走行環境 の一般性を損なうものではない.なお，一般的な障害物, すなわち光源等を備えていない障害物の検知ならびに回避 のためには, 別途センサシステムを準備する必要がある が，本論では扱わない.

位置・姿势計測は, 能動的方法と受動的方法とに大別され る. 計測側が光や音波を投射する前者は複雑な環境での高速計 測に適するといわれるが, 複数台のロボットが存在すると相互 干涉の問題が発生する. 後者の受動的方法のうち, 被測定物の 視覚的形状に依存する方法では, 環境変化に脆弱であることが 予想される.そこで本論では, 移動ロボット上の被計測側に点 光源を配置した看板を揭げ，その形と大きさを別のロボットで ある計測側の CCD カメラで読み取る方式（Fig. 1) を提案す る. 本方式の位置・姿勢実時間計測システム実現のためには, 


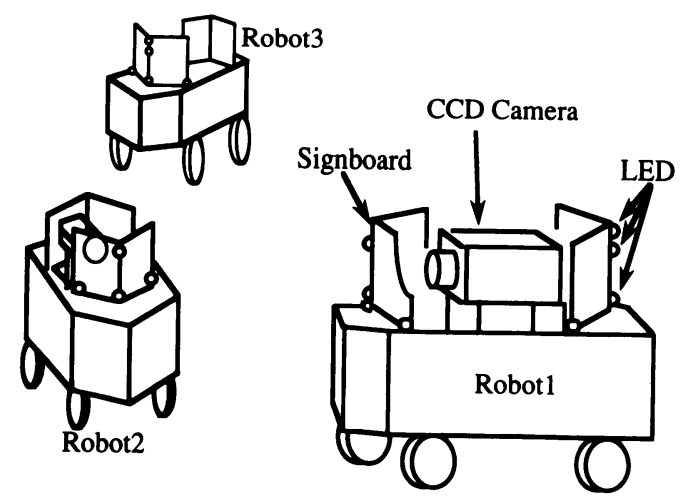

Fig. 1 Schematic View of the Proposed System

(a) 『看板』上の点光源配置設計法

（b） CCD カメラの画像情報からの相対位置・姿勢の計算ア ルゴリズム

の 2 点が重要である. 前者に関しては 2.2 節で, 後者に関して は 2.3 節で述べる．また，本論文では，カメラの視線方向制御 に関する議論は行わない.

\section{2 看板の基本設計}

「看板』(signboard) とは被計測側に搭載された，計測側から 識別しやすく，位置・姿勢を計測しやすい物体である，本研究 では移動ロボットの位置と姿勢を実時間で計測するのが目的で あるから、

（1） 全方向性：被計測側ロボットがどの方向を向いていて も位置・姿勢を計測できること，

（2）単純な画像処理アルゴリズム：実時間で処理可能でか つ移動ロボットに搭載しやすいこと

を要求仕様と考え,

(1) $4 \sim 5$ 個の発光ダイオードを点光源として用い,

(2) ロボット間距離への非依存量（例えば 3 点間の 2 つの距 離の比）を利用して，看板の認識，姿勢の計測をし，

(3) ロボット間距離への依存量（例えばカメラ撮像面上での 距離）を利用して，奥行方向の距離を計測する， ことを基本原理とするシステムを構成する．また測定範囲を $0.5 \mathrm{~m} \sim 3.0 \mathrm{~m}$ と限定する. あまり近くではその後の回避行動 がとりにくくなるため意味がなく，あまり遠くでは，衝突の可 能性が低いからである．さまざまな看板が設計可能であるが， 本研究では，Fig. 2 のように，折れ曲った 2 枚の板上に点光源 を少数配置した方式を採用する．1枚の板からなる看板では回 転によって端点の光源の検出が困難となるので，観察可能範囲 は $360^{\circ}$ に満たない．そこで，Fig. 2（a）（b）に示すように 2 枚 を開き角 $\alpha\left(0^{\circ}<\alpha<180^{\circ}\right)$ で組合せた構造を採用する．以降， この構造を「看板要素」と呼ぶ. $\alpha$ は計測範囲と計測精度の両者 に影響を及ほす，単一の看板要素を観察可能な範囲の理論值は $(360-\alpha)^{\circ}$ であるので, $90^{\circ}<\alpha<180^{\circ}$ なる看板要素 2 組を対向 させてロボット 1 台用の看板システムを構成する (Fig. 2 (c)). 開き角 $\alpha$ の設計については 4 章で述べる.

\section{2 .1 看板の認識と分離}

移動ロボットは水平面上を移動し, 倒れは無いと仮定してい るため, ロボットの高さは変化しない. カメラを水平に設置

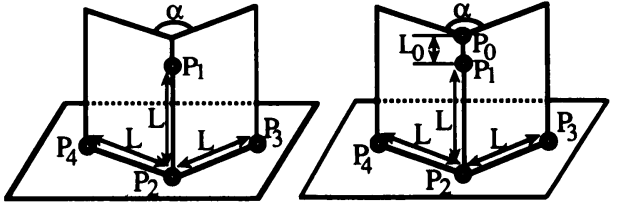

(a) Signboard UnitA

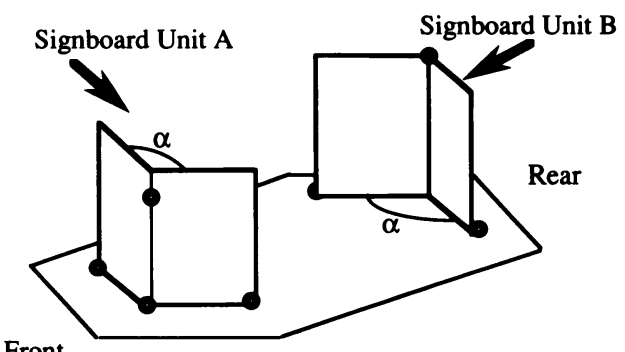

Front

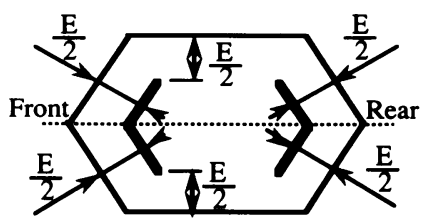

(d) A Top View of Signboard

Fig. 2 Schematic View of Signboard

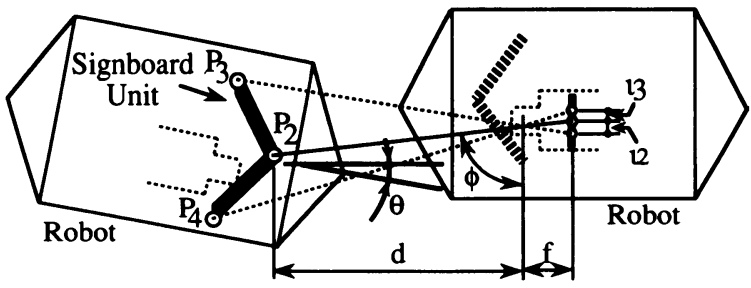

f: the focus distance

Fig. 3 Relationship between Signboard and Camera

し, 点光源 $P_{1}$ をカメラのレンズ光軸と同一高さに設置する. この結果, すべての移動ロボットの点光源 $P_{i 1}$ は必ず水平面上 同一高さとなりレンズ光軸上で観察される. この輝度 $P_{i 1}$ を取 掛かりとし，その上下に他の点光源が存在することで看板を認 識する。これより画像処理の負荷を大幅に軽減でき，実時間処 理が実現される.

1 台のロボットの前後判別は，Fig. 2(b)で分かるように点 光源 $P_{1}$ の上方に点光源 $P_{0}$ を追加し, $P_{0}$ が存在すれば看板要 素 $B$ で後, なければ看板要素 $A$ で前であるとする. 看板要素 上には 4 つの光源が Fig. 2(a)のように一定距離 $L$ で配置さ れている. 複数のロボットはある看板要素が他の看板要素を隠 蔽することを基本に分離する，すなわち，Fig. 2(d)における $E>L$ とすれば，看板要素毎の分離が可能となる．これについ ては 3.1 節で説明する。

\subsection{2 ロボット間の相対位置・姿勢の計測}

ロボット間の相対位置・姿勢の計測は, 看板の点光源像から Fig. 3 における看板までの距離 $d$, 方向 $\phi$, 看板の姿勢 $\theta$ の 
健太郎太田順梅田和昇

值を一義的に決定することである

ロボットが遠くに存在すれば，垂直距離 $\overline{P_{1} P_{2}}$ の像はロボッ 卜間距離に反比例して小さくなるため, 像から距離 $d$ を逆算 することが可能である. なお, $\overline{P_{1} P_{2}}$ はロボットの鉛直軸周り の回転 $\theta$ に対して不変量である. 次に CCD 面上の像の位置か ら $\phi$ 求めて, ロボットの位置が確定する.

ロボットが鉛直周りに $\theta$ だけ回転した時，垂直距離は不変 量であるが, 水平距離 $\overline{P_{2} P_{3}}$ の像あるいは $\overline{P_{2} P_{4}}$ の像は距離 $d$ の 余弦関数として変化する. しかし $\overline{P_{2} P_{3}}$ と $\overline{P_{2} P_{4}}$ とのカメラ撮像 面上での長さの比は，距離には依存せず相対姿勢 $\theta$ のみの 関数となる.よって, $\overline{P_{2} P_{3}}$ の像と $\overline{P_{2} P_{4}}$ 像の比から $\theta$ が逆算で きる.

\section{3. 画像処理アルゴリズム}

複数個の看板を撮影した画像上での点光源配置の例を Fig. 4 に示す.この画像情報から，複数台のロボットの位置・姿勢を 計算するアルゴリスムは以下の手順で構成される.

1. 各看板要素の分離

2. 各看板要素との相対位置・姿勢の計算

3. 看板を搭載するロボットとの相対位置・姿勢計測

3.1 各看板要絭の分離

以下に示すアルゴリズムにより各看板要素の分離を実現す る.

（a）レンズ光軸上を走査して輝点を見つける. $n$ 個検出され たら，それらは皆看板要素の第 1 光源 $P_{11} \sim P_{n 1}$ と仮定する.

(b) すべての $P_{i 1}$ に対して以下の処理を行う.

(b-1) $P_{i 1}$ の下方を画面上で $L f / d$ minだけ探索して, $\overline{P_{i 1} P_{i 2}}$ から計測対象までの距離 $d_{i}$ を求める.ここ で, $L$ は輝点 $p_{1} p_{2}, p_{2} p_{3}, p_{3} p_{4}$ 間の距離, $f$ はカメラ の焦点距離, $d$ min は計測範囲の最短距離である.

(b-2） $P_{i 1}$ の上方を画面上で $L_{0} f / d_{i}$ だけ走查して $P_{i 0}$ を探 す. $L_{0}$ は輝点 $p_{0} p_{1}$ 間の距離である.

(b-3) $P_{i 2}$ の左右を $L f / d_{i}$ だけ走査して，最初に発見した輝 点をそれぞれ $P_{i 3}, P_{i 4}$ とする.

なお，探索している輝点を発見できなかった場合には，元の輝 点はノイズと判断して, 続く処理を停止する.

さて，上記のアルゴリズムにおいて画面上での探索範囲は， 看板上で対象とする輝点までの長さを画面で計測できるであろ う距離に置き換えたものである.（b-3）においては，隣の看板

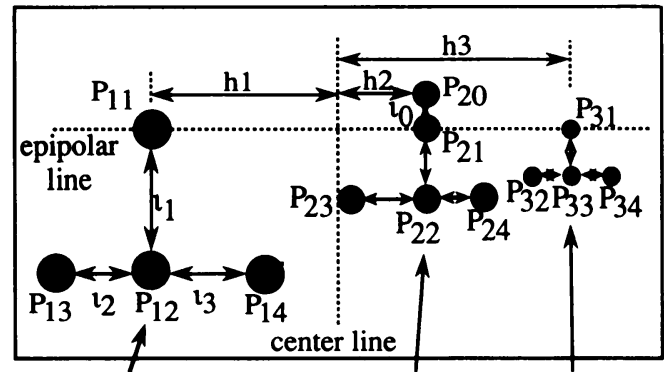

Image of Robot 1 Image of Robot 2 Image of Robot 3 (short distance) (middle distance) (long distance)

Fig. 4 An Example of Images of CCD Camera
上の輝点を同一看板に属すると見誤る可能性がある．それを排 するために，看板要素は Fig. 2(d) 上に示す台上に設置され， 周囲から必ず $E / 2$ だけ離れていると保証しておく．すると，

-奥行方向に相対距離の異なる看板要素の輝点は画面上で異な る基線高さで存在する.

・同一相対距離の看板要素の輝点は, 必ず最低 $E$ だけ離れて

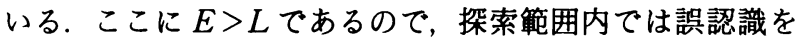
起こさない.

であるから看板要素を分離することができる.

\section{2 各粍板要率との相対位目・姿势計算}

以下に Fig. 3 の $d, \phi, \theta$ の導出アルゴリズムを示す.

（a） カメラの見込角 $\phi$ を, 式（1）を用いて求める.

$$
\phi=\tan ^{-1} \frac{f}{h} \quad\left(0<\phi<180^{\circ}\right)
$$

ここに Fig. 4 に示すように $h$ は画像中心から $P_{i 1}$ の像までの 水平方向の距離を意味する.

(b) 相対距離 $d$ を式 ( 2 ) から求める. $l_{1}$ は画像上の $\overline{P_{1} P_{2}}$ で ある.

$$
d=\frac{L f \sin \phi}{l_{1}}
$$

（c）相対姿勢 $\theta$ の計測は，いくつかの輝点を検出したかに より，次式(3)-(5)をそれぞれ用いる. $P_{2}, P_{3}, P_{4}$ をすべて検 出できた場合には式( 3$)$ を, $P_{2}, P_{3}$ を検出できて $P_{4}$ が検出で きなかった場合には式(4)を， $P_{2}, P_{4}$ を検出できて $P_{3}$ が検出 できなかった場合には式 $(5)$ を，それぞれ用いることとする.

$$
\begin{gathered}
\theta=\tan ^{-1} \frac{G_{2}}{G_{1}} \frac{\pi-\alpha}{2} \\
\theta=\cos ^{-1} \frac{-l_{2} d}{L f \sqrt{1+A^{2}}}-\sin ^{-1} \frac{f \cot \phi-l_{2}}{f \sqrt{1+A^{2}}}-\frac{\pi+\alpha}{2} \\
\theta=\cos ^{-1} \frac{l_{3} d}{L f \sqrt{1+B^{2}}}-\sin ^{-1} \frac{f \cot \phi+l_{3}}{f \sqrt{1+B^{2}}}-\frac{\pi-\alpha}{2}
\end{gathered}
$$

ただし，

$$
G_{1}=l_{2} f+l_{3} f \cos \alpha+\left(l_{2} l_{3}-l_{3} f \cot \phi\right) \sin \alpha
$$

$$
G_{2}=l_{2} l_{3}+l_{2} f \cot \phi+l_{3} f \sin \alpha-\left(l_{2} l_{3}-l_{3} f \cot \phi\right) \cos \alpha
$$

$$
A=\cot \phi-\frac{l_{2}}{f} \quad B=\cot \phi+\frac{l_{3}}{f}
$$

$-180^{\circ}<\theta \leqq-90^{\circ}, 90^{\circ}<\theta \leqq 180^{\circ} \quad\left(P_{0}\right.$ が存在する場合）

$-90^{\circ}<\theta \leqq 90^{\circ} \quad\left(P_{0}\right.$ が存在しない場合 $)$

ここで, 式(4)（5）を用いた場合には， $\theta$ の解が 2 通り存在 することに注意されたい，これは，Fig.5に示すような， $P_{3}$ あるいは $P_{4}$ のどちらかが障害物等の存在により隠蔽されてい る状況を意味する．このとき，上記のアルゴリズムを用いる と, 解として Fig. 5(a)の実線の姿勢の対する解 (i ) と破線の 姿勢に対する解 ( ii )2つが得られる. その対策として, 本論で は, $P_{3}$ または $P_{4}$ 光源の $\mathrm{CCD}$ 画面上の綐方向位置が異なるこ とを利用して $\theta$ を一義的に决定する (Fig. 5(b)). この偏差が 小さい時には，誤認識をする可能性があるが，これは，Fig. 5 （a ）の解( i )，（ii）の姿勢の差が非常に小さい場合，あるいは 遠方を計測している場合を意味しているため，実用上差し支え ない程度の諤差であると考えられる.

また，あるロボットの看板情報 $P_{3}, P_{4}$ の両者が他のロボット 等により隠蔽されて，姿勢情報が検出できない場合も想定でき 


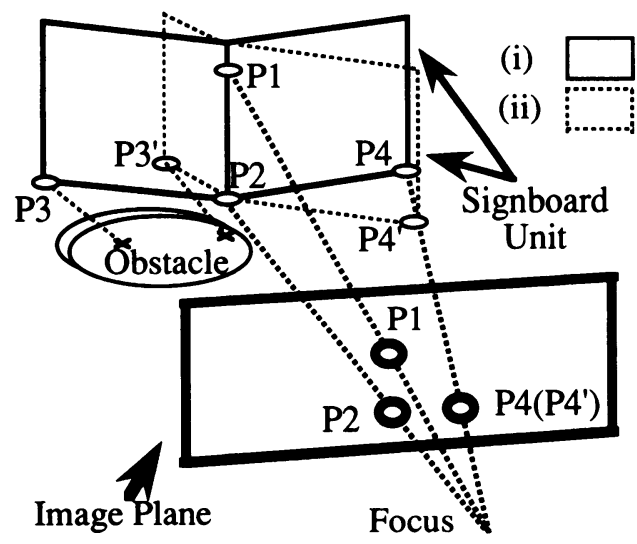

(a)

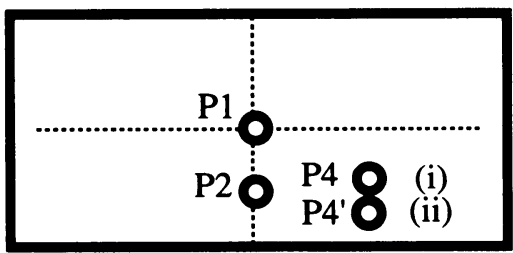

(b)

Fig. 5 An Example of Two Answers of Orientation

る.このような遠方にあり視界から遮られているロボットの情 報は，むしろ獲得したくないものと考えられるため，上記の想 定も実用上差し支えない，

3.3 看板を搭載するロボットとの相対位置・姿勢計測

1 つの看板システムは Signboard Unit $A$ と $B$ の 2 つの看 板要素から構成されている. そこで, 画像上の隣接した看板要 素が同一のロボットに属するかの判別が必要となる. 本論で は, 互いに隣り合った看板要素同士が，（a 相対位置がほほ等

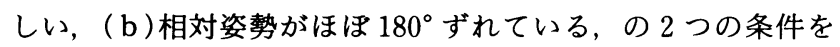
満たしている時, その 2 つが, 同一のロボットの一組の看板要 素であるとみなす．これより，2 つの看板要素の位置・姿勢計 測結果の加重平均により, 最終的に各ロボットとの相対位置・ 姿勢が計測できる. 一方, 1 つのロボットに対して 1 つの看板 要素のみが計測された場合には, 看板要素の位置・姿勢計測值 に，ロボット中心・看板間の相対位置・姿勢オフセットを加え た值を，最終的なロボットの相対位置・姿勢とすることができ る.

\section{4. 誤差解析による看板の設計}

本章では，看板の形状設計法について論じる．まず，4.1節 で誤差解析を行う. 次に，その理論式に基づいて 4.2 節で $L$, $\alpha$ を求める.

\section{1 看板の誤差解析}

計測環境が理想的なものであるとすると，計測誤差を生じる 要因は, CCD カメラの撮像面に点光源の像を取り込む際の標 本化誤差によるものであると推定できる. 本節ではその影響に ついて解析し， $L, \alpha$ の設計に用いる. カメラの焦点距離 $f$ は
固定する.

$d$ と $\theta$ の $l_{1}$ に対する感度を求める. 式 ( 2$) の d$ と $l_{1}$ の関係 式より, 距離の標準偏差を $\sigma_{d}, l_{1}$ の標準偏差を $\sigma_{1}$ とすれば, 式( 6 )が得られる.

$$
\sigma_{d}=\frac{d^{2}}{L f \sin \phi} \sigma_{1}
$$

よって, $\mathrm{CCD}$ カメラ上での標本化による位置の誤差は $d$ を 一定とすれば, 点光源の間隔 $L$ に反比例する.

一方, 姿勢に関しては, 姿勢の標準偏差を $\sigma_{\theta}, l_{2}, l_{3}$ の標準偏 差をそれぞれ $\sigma_{2}, \sigma_{3}$ とおけば

$$
\sigma_{\theta}=\sqrt{\left(\frac{\partial \theta}{\partial l_{2}}\right)^{2} \cdot \sigma_{2}^{2}+\left(\frac{\partial \theta}{\partial l_{3}}\right)^{2} \cdot \sigma_{3}^{2}}
$$

が得られる.ここで, 誤差に一様分布を仮定し， $\lambda$ を撮像面一 画素の長さとすると, $\sigma_{2}=\sigma_{3}=\lambda \sqrt{3} / 6$ とみなせるから

$$
\sigma_{\theta}=\frac{\lambda \sqrt{3}}{6} \sqrt{\left(\frac{\partial \theta}{\partial l_{2}}\right)^{2}+\left(\frac{\partial \theta}{\partial l_{3}}\right)^{2}}
$$

となる. 式( 8 )が, 標本化誤差の姿勢測定への影響式である. $\frac{\partial \theta}{\partial l_{2}}, \frac{\partial \theta}{\partial l_{3}}$ は, $\theta$ の求め方に応じて異なる. まず, $P_{1} P_{2} P_{3} P_{4}$ を用 いて計測する場合には, 式 ( 3$)$ を $l_{2}, l_{3}$ で微分して,

$$
\begin{gathered}
\frac{\partial \theta}{\partial l_{2}}=\frac{\left(l_{3}+f \cot \phi-l_{3} \cos \alpha\right) G_{1}-\left(f+l_{3} \sin \alpha\right) G_{2}}{G_{1}^{2}+G_{2}^{2}} \\
\frac{\partial \theta}{\partial l_{3}}=\frac{G_{2 d} \cdot G_{1}-G_{1 d} \cdot G_{2}}{G_{1}^{2}+G_{2}^{2}}
\end{gathered}
$$

ただし， $G_{1}, G_{2}$ は式 ( 3 )の $G_{1}, G_{2}$ と同じ. また，

$G_{1 d}=f \cos \alpha+\left(l_{2}-f \cot \phi\right) \sin \alpha$

$G_{2 d}=l_{2}+f \sin \alpha-\left(l_{2}-f \cot \phi\right) \cos \alpha$

が得られる. 一方 $P_{1}, P_{2}, P_{3}$ のみで計測を行う場合は

$$
\sigma_{\theta}=\frac{\lambda \sqrt{3}}{6}\left|\frac{\partial \theta}{\partial l_{2}}\right|
$$

であるから，式 (4)を $l_{2}$ で微分して,

$$
\frac{\partial \theta}{\partial l_{2}}=\left\{\begin{array}{l}
\frac{1}{l_{u}^{2}+f^{2}}\left\{\frac{d\left(l_{u}^{2}+f^{2}+l_{2} l_{u}\right)}{\sqrt{L^{2}\left(l_{u}^{2}+f^{2}\right)-d^{2} l_{2}^{2}}}+f\right\} \\
\left(\theta+\sin ^{-1} \frac{l^{2}}{\sqrt{f^{2}+l_{2}^{2}}} \geqq 0 \text { の時 }\right) \\
\frac{1}{l_{u}^{2}+f^{2}}\left\{-\frac{d\left(l_{u}^{2}+f^{2}+l_{2} l_{u}\right)}{\sqrt{L^{2}\left(l_{u}^{2}+f^{2}\right)-d^{2} l_{2}^{2}}}+f\right\} \\
\left(\theta+\sin ^{-1} \frac{l^{2}}{\sqrt{f^{2}+l_{2}^{2}}}<0 \text { の時 }\right)
\end{array}\right.
$$

ただし， $l_{u}=f \cot \phi-l_{2}$

が得られる. $P_{1} P_{2} P_{4}$ のみで計測を行う場合も式 $(5)$ を $l_{3}$ で微 分することにより同様の式を得られる.

\section{2 看板の設計}

\section{2 .1 点光源間の距離 $L$ の設計}

式 ( 6 ) に示すように位置計測の理論的誤差は点光源間の距離 $L$ が大になるほど小さくなる, 実装するロボットの大きさに よる制約を受ける，すなわち，Lはロボットに搭載できる程 度に大きく設計することが望ましい. 一方, $\overline{P_{0} P_{1}}=L_{0}$ は画素 の分離能から決定する.

\section{2 .2 姿勢計測用の点光源間角 $\alpha$ の設計}

看板の基本設計で明らかにしたように，2枚の看板を組合せ て看板要素を構成し， 2 組準備して全方向からの姿勢測定を可 能としている. 看板要素での開き角 $\alpha$ は回転の見えやすさと 


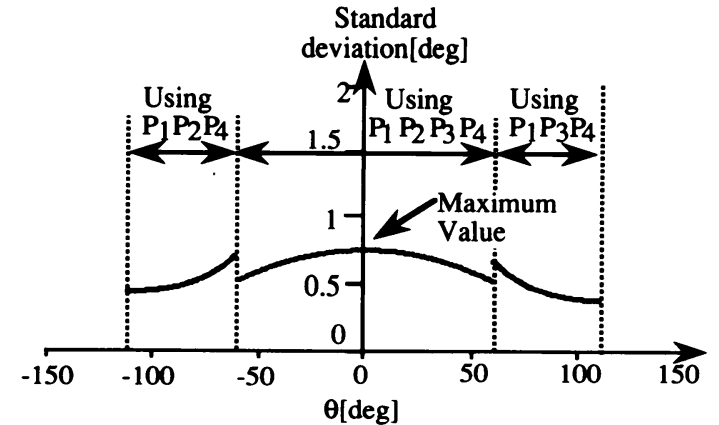

Fig. 6 Relationship between $\theta$ and Standard Deviation of Error $\left(\alpha=140^{\circ}\right)$

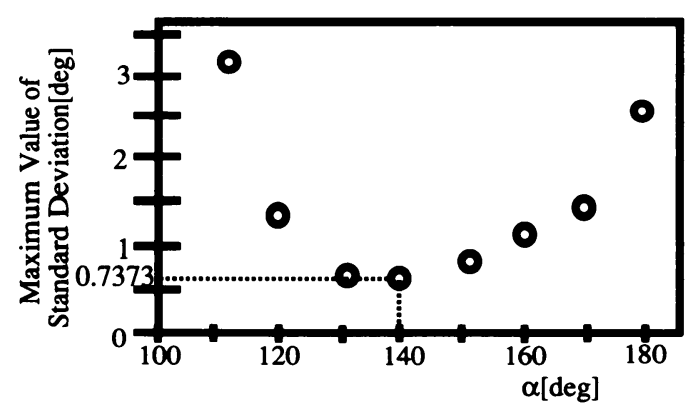

Fig. 7 Relationship between $\alpha$ and Error

測定誤差とに影響するので, 式（８）(11）を用いて $\alpha$ を設計する. $\alpha=140^{\circ}$ で, $L=0.07 \mathrm{~m}, \phi=90^{\circ}$ に固定して $\theta$ を $-90^{\circ} \sim 90^{\circ}$ まで変化させた場合の, 標本化誤差を原因とする回転角度 $\theta$ 測定時の標準偏差を Fig. 6 に示す．見える輝点によって区分 されているが, 正面 $\left(\theta=0^{\circ}\right)$ で最大誤差を有することが分か る.これは，看板が正面を向いている時に，姿勢変化に対する 測定值の感度が最も低くなると意味している. 次に Fig. 6 と 同じく, $L=0.07 \mathrm{~m}, \phi=0^{\circ} て ゙$, 開き角 $\alpha$ の変化に対する姿勢 測定誤差の標準偏差の最大值を Fig. 7 に示す. $\theta=140^{\circ}$ あたり で最も誤差の小さいことが理解できる.これは,

・ $\alpha>140^{\circ}$ とすると, 正面を向いている時の誤差の標準偏差が 増大する,

- $\alpha<140^{\circ}$ とすると, $P_{1} P_{2} P_{3} P_{4}$ を用いた計測領域と $P_{1} P_{2} P_{3}\left(P_{1} P_{2} P_{4}\right)$ を用いた計測領域の境界における誤差の標準 偏差が, 正面を向いている時の誤差の標準偏差を上回る, ことが原因である．今後， $\alpha$ は $140^{\circ}$ を採用する.

\section{5. 検 証 実 験}

\section{1 実験システムの概要}

4 章までで設計した手法の有効性を実証するため, Fig. 8 に 示す計測システムを試作し，実験を行った.

移動ロボット $(270[\mathrm{~mm}] \times 170[\mathrm{~mm}] \times 188[\mathrm{~mm}])$ の上部に看 板及び CCD カメラ $(f=12[\mathrm{~mm}])$ を搭載した。看板の寸法を $L=0.07[\mathrm{~m}], L_{0}=0.02[\mathrm{~m}]$ とした. 点光源には高輝度 LED （シャープ製 GL5LR60）を用いた。これより，一般の照明下に おいて, 点光源を安定的に検出できた. 看板情報を CCD カメ ラを介してフレームメモリ $(512 \times 256$ 画素, 8 bit $)$ に取込み, パーソナルコンピュータ $(80486 \mathrm{CPU}, 25 \mathrm{MHz})$ で, 実時間計

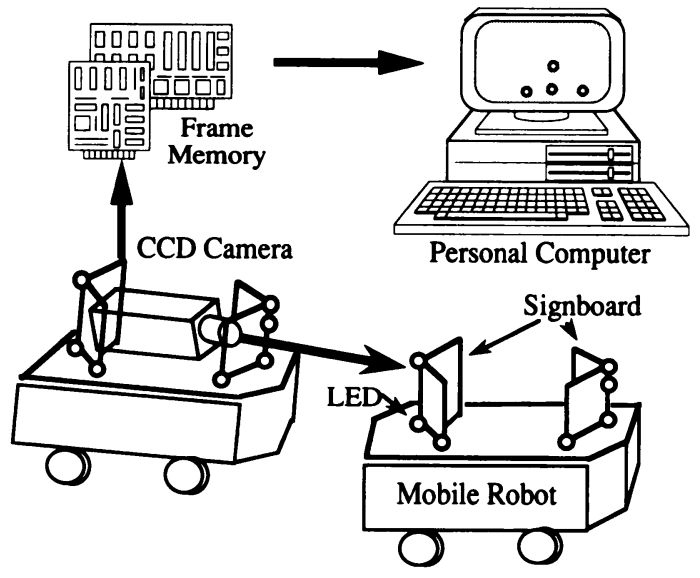

Fig. 8 Experimental System

測を行う。

\section{2 実験の概要}

試作システムの計測精度と計測時間を評価するために，以下 の 3 種類の実験を行った.

（E-1） 精度を評価する 1 台のロボットの計測実験

（E-2） 時間を評価する複数台ロボットの計測実験

（E-3） 運動しているロボットの精度を評価する走行ロボット の計測実験

以下の実験において, 点光源 $P_{1}$ を検出する信頼性を增すた めに, $P_{1}$ の走查領域を上下方向 10 画素に設定して，探索を実 現している。

\section{3 実験結果}

5.3.11台のロボットの計測実験

実験は, 以下の 2 種類について行った.

(a) 位置精度を計測するためにカメラとの相対位置を $0.5[\mathrm{~m}]$ より $3[\mathrm{~m}]$ まで $0.5[\mathrm{~m}]$ 刻みで，看板を計測した。姿勢 は $0^{\circ}$ 及び $45^{\circ}$ に固定して 20 回ずつ計測した.

（b）姿勢精度を計測するために，姿勢を $-180^{\circ}$ から $180^{\circ}$ ま で $15^{\circ}$ 回転ずつさせた看板を計測した.

実験結果を Fig.9に示す．姿勢計測に関しては，1 [m]，2 $[\mathrm{m}], 3[\mathrm{~m}]$ の場合とも同様な結果が得られたが, 代表例とし て $2[\mathrm{~m}]$ の場合のみを示す. Fig. 9 の結果より, 位置に関して $5 \%$ 以内の誝差で計測結果が得られており，位置・姿勢計測值の 誤差の平均値, 標準偏差が理論誤差の範囲内に収っていること が分かる. カメラの見込角 $\phi$ を変化させた時にも, 同様の結 果が得られた。これより，レンズ収差の影響は無視できると考

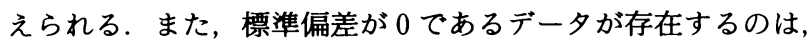
フレームメモリの $A / D$ 変換の量子化効果により測定誤差が吸 収されたものであると考えられる。

\subsection{2 複数台ロボットの計測結果}

2 台または 3 台のロボットを任意の位置・姿勢に固定させた 時の各ロボットごとの位置・姿勢を計測した. 計測時間の結果 を Fig. 10 に示す.この結果より， 1 台のロボットで 0.2 秒強 の計測時間, $n$ 台のロボットが存在した時には $(0.12+0.09 n)$ 秒で計測できるが，1台のカメラの視野内に入るロボットはた かだか 5〜6台であると考えられるため, 実時間処理が十分可 


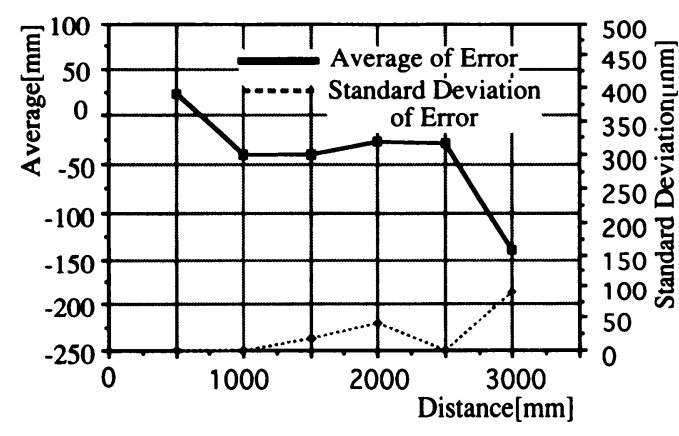

(a)

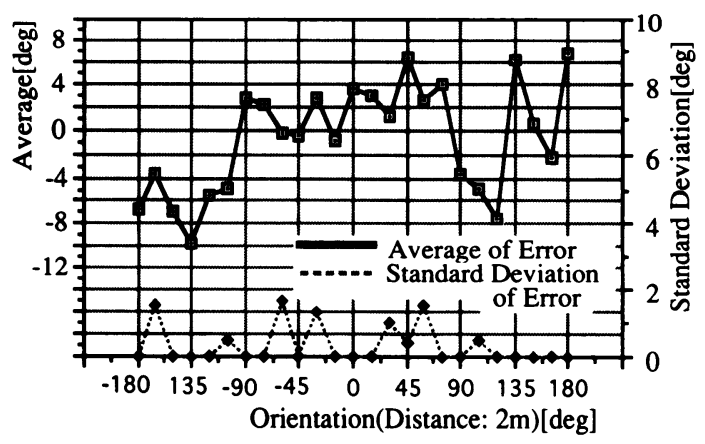

(b)

Fig. 9 Experimental Results on (E-1)

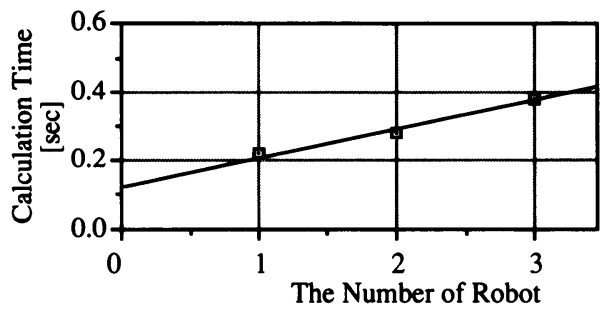

Fig. 10 Relationship between Calculation Time and the Number of Robot

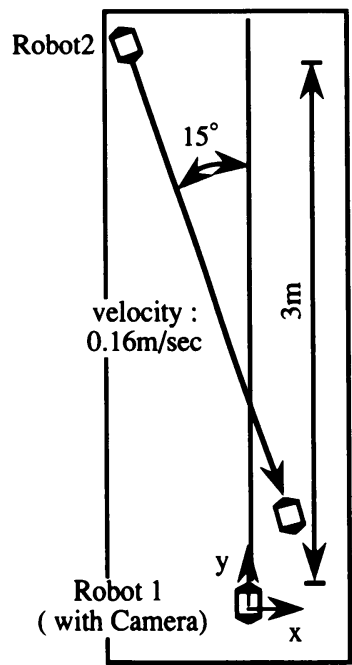

Fig. 11 Trajectory of Moving Robots

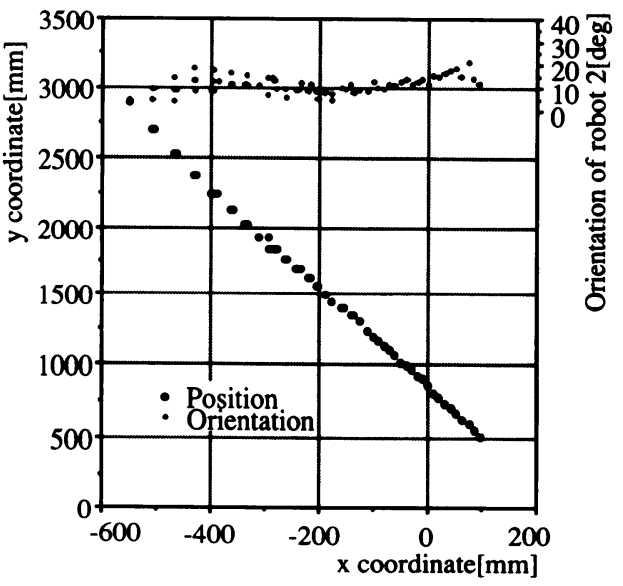

Fig. 12 Experimental Results on Measurement of Position and Orientation of the Moving Robots

能であると考えられる.

5.3.3 ロボット走行時の計測実験結果

Fig. 11 に示すように，ある一定の角度で定速走行している ロボット（ロボット 2 ） との相対位置・姿勢, 静止したロボッ ト（ロボット 1) のカメラから計測する実験を行った。実験結 果を Fig. 12 に示す.

誤差に関しては，移動ロボット自身の走行誤差も含まれてい るため実験(E-1)の場合よりも大きな誤差が検出されている が，実用的には問題ないと考えられる.

本論では環境として平坦な地形を仮定したが，多少の起状が ある環境にも， $P_{1}$ の走査領域を上下方向に広げることにより 対応可能である.

\section{6. 結 論}

本研究は複数移動ロボット系の相対位置・姿勢相互計測シス テムとして，実時間処理の可能なシステムを提案したものであ り，以下に示す成果が得られた。

・各ロボットの計測部として『カメラ』と「看板」からなるシ ステム構成を提案した。

・誤差解析により看板の設計を行い, 画像情報からの位置・姿 勢計測アルゴリズムを提案した.

・検証実験により相対位置に関して $5 \%$ 程度の精度が得られ, 手法の有効性を実証した.

今後の課題としては, 位置・姿勢情報伝達の概念を拡張した 移動ロボット相互の通信システムへの応用が考えられる.

\section{参 考 文 献}

[1] 新井民夫, 太田 順：複数移動ロボット系の計画. 日本ロボット学会 誌, vol. 10, no. 4, 444-449, 1992.

[2] 斉 丙辰, 大川善邦：移動ロボットの誘導のための立体標識. 日本口 ボット学会誌, vol.9, no. 2, 129-136, 1991.

[ 3 ] 藤原直史, 米澤 徹, 津村俊弘 : 画像情報を利用した移動体の位置姿 勢計測法. システム制御情報学会論文誌, 3, 4, 110-117, 1990 .

[4] 津村俊弘, 橋本雅文, 藤原直史 : レーザとコーナーキューブを利用し た 3 次元移動体の能動位置計測法. 日本ロボット学会誌, vol. 6, no. 1, $26-34,1988$

[ 5] 津村俊弘：複数ビークルにおける協調制御. 1992 年度機械学会ロボ 
cooperation. 9th Int. Symp. Automat. Robotics in Construction, 887-896, 1992.
[6] Yuta, S., Premvuti, S. : Design and implementation of multiple autonomous roobots' cooperative behavior. based on modest

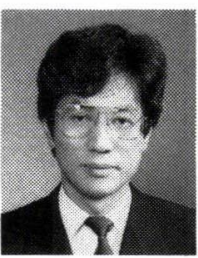

新井民夫（Tamio Arai）

1947 年 8 月 4 日生. 1970 年東京大学工学部精密機 械工学科卒, 1977 年同大学大学院博士課程修了工 学博士. 1987 年同大学同学部同学科教授. 1979 年 ～1981 年英国エディンバラ大学人工知能学科研究 員. 産業用ロボット言語の標準化活動を推進. 自 動組立, 距離画像処理などの研究に従事. 精密工 学会理事, 自動化推進協会会長.

(日本ロボット学会正会員)

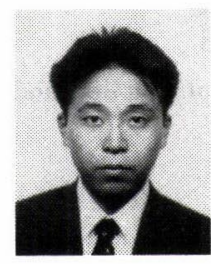

\section{前田健太郎 (Kentaro Maeda)}

1970 年 2 月 28 日生. 1992 年東京大学工学部精密 機械工学科卒業. 同年新日本製鉄(株) 入社. 現在 同八幡製鉄所薄板・亜鉛メッキ鋼板部に所属. 冷間 圧廷ミル周辺の企業・開発に従事. 日本鉄鋼協会会 員.

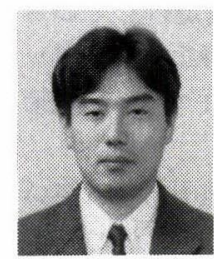

梅田和昇 (Kazunori Umeda)

1967 年 2 月 6 日生. 1989 年東京大学工学部精密機 械工学科卒, 1991 年同大学大学院工学系研究科精 密機械工学専攻修士課程修了. 同年同博士課程進 学, 現在に至る. ロボットビジョンの研究に従 事. 情報処理学会, 精密工学会の会員.

(日本ロボット学会学生会員)

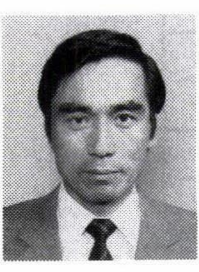

木村久幸 (Hisayuki Kimura)

1944 年 2 月 6 日生. 1965 年横浜国立大学工業教員 養成所機械工学科卒. 1973 年同工学部II部機械工 学科卒. 神奈川県立磯子工高教諭. 同向の岡工高 教諭. 1989 年より神奈川県立商工高教教諭. 機械 科の計測・制御を担当. 精密工学会, 日本産業技術 史学会の会員.

(日本ロボット学会正会員)

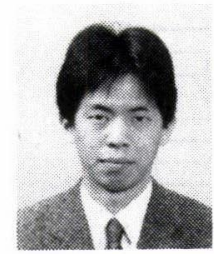

\section{太田 順 (Jun Ota)}

1965 年 2 月 19 日生. 1989 年東京大学工学系大学 院精密機械工学専攻修士課程修了. 同年新日本製 鐵 (株) 入社. 1991 年東京大学工学部助手. ロボッ トのプランニング, 制御の研究に従事. 精密工学 会, IEEE 会員.

（日本ロボット学会正会員） 